\title{
Action Research In Teacher Preparation: An Inclusive Seminar
}

Elissa Poel, (E-mail: epoel@nmsu.edu), New Mexico State University

Carolyn Dietrich, (E-mail: dietrich@nmsu.edu), New Mexico State University

\begin{abstract}
The article focuses on a teacher education program at a Carnegie I Research Institution in the southwestern part of the United States; also, classified as a minority-serving institution. Teacher candidates in elementary, special, and bilingual education were enrolled in a combined student teaching seminar which is a collaborative initiative between the Departments of Special Education/Communication Disorders and Curriculum and Instruction. The authors of this manuscript are the researchers, seminar instructors, and directors of their student teaching components. The purpose of this study was to determine the effectiveness of action research with teacher candidates during the student teaching semester. The research question that guided this research is: How effective is the use of action research with teacher candidates to determine evidence of student learning in the K-12 classroom?
\end{abstract}

\section{ACTION RESEARCH IN TEACHER PREPARATION: AN INCLUSIVE SEMINAR}

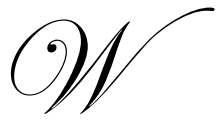

hen our teaching practices change, we tend to gain an awareness of what we are doing and find ourselves in a better position to help each other write about our work and achieve ongoing renewal of our practice (Kosnik \& Beck, 2002). Trends in education in the United States have moved toward aligning curriculum with federal mandates, state initiatives, and grade-level standards. Classroom practices now must include scientifically based research practices in program design and implementation. As researchers, who also serve in roles as seminar instructors and the directors of a student teaching program in a southwestern borderland university, we have struggled with accountability issues as outlined in the No Child Left Behind (NCLB) Act; the Individuals with Disabilities Education Improvement Act (IDEIA) 2004; and state legislation. Our teacher preparation program is aligned with the National Council for Accreditation of Teacher Education (NCATE) and the Council for Exceptional Children (CEC) which highlights teacher accountability. Because of this, we felt the need to incorporate ways for our teacher candidates to provide evidence of student learning in their classrooms and help them to "connect the relationship between explicit research and thoughtful practice" (Kosnik \& Beck, 2002, p. 2). Hence, we chose to pilot an action research project to be our avenue to scientifically based research because action research reflects what teachers naturally do in the classroom. Teachers assess current knowledge, plan and implement student centered curricula, evaluate student learning, and effect change in teacher practices and student learning (Auger \& Wideman, 2000; Henderson, Hunt, \& Wester, 1999; Holly, Arhar, \& Kasten, 2005).

Historically, teacher candidates were required to collect evidence of student learning (EOSL) via the traditional pre- and post-test model. They would develop and administer a pre test to determine prior knowledge or skill level as it related to unit content. Then, they would analyze the pre test data in order to plan their units that were aligned with state standards and benchmarks, grade-level curriculum, and IEP goals and objectives. They would deliver this unit and follow-up with a post test to determine student achievement as a result of their teaching efforts. Post-test data was analyzed and compared to pre-test data in order to determine academic growth and, specifically, where that growth took place.

The purpose of this action research study was to determine the effectiveness of action research with teacher candidates during their student teaching semester. We wanted to know if adding the components (literature review and personal statements) of an action research study to the initial evidence of student learning requirement was, indeed, 
worth the effort - the effort on the student's part to conduct research during their student teaching semester and on our part as seminar instructors to direct and guide a research study for each of our 54 teacher candidates. The question guiding this research was: How effective is the use of action research with teacher candidates to determine evidence of student learning in the K-12 classroom?

Rationale

In order to help teacher candidates improve their teaching skills and become reflective practitioners, they are required to maintain a daily journal where they would reflect on their teaching, insights, feelings, perceptions, and impressions of their teaching delivery and lesson content (Chant, Heafner, \& Bennett, 2004; Rosaen \& Gere, 1996). Moore (1999) states, “...the process whereby a teacher reflects on teaching actions and beliefs in relation to learner responses and reactions suggests some rich opportunities in pre-service teachers' field experiences" (p. 1). Our professional analysis of the journals and EOSL projects identified a missing link, which was current research in teacher practices. This finding determined the need to incorporate current research through a literature view into the EOSL project.

\section{METHODOLOGY}

The study took place at a Carnegie I Research Institution in the southwest region of the United States. This university also is classified as a minority-serving institution where approximately $47 \%$ of its student body and nearly $20 \%$ of its faculty represent diverse cultural, linguistic, and ethnic minority groups including those with disabilities. Fifty-four teacher candidates in elementary education (34), special education (15), and bilingual education (5) were enrolled in the student teaching seminar on main campus at the time of the study and participated in the project: 6 were male and 48 were female. Their ethnicity included 33 Hispanic, 9 Anglo, 1 American Indian, 1 Asian, and 10 Other.

\section{PROCEDURES}

During the weekly seminar activities, students were given an overview of the Action Research (AR) project along with the purpose for conducting action research in their classrooms. Each component (Research Question, Purpose/Rationale, Literature Review, Methodology, Data Collection, Data Analysis, Observations and Conclusions, Implications, and Personal Statement) was presented and discussed at separate seminars with time between for teacher candidates to draft and revise. Drafts were peer reviewed and sent electronically to the seminar instructors for input. Action research projects were shared during the final seminar and written manuscripts were submitted to the instructors.

Initially, teacher candidates were directed to reflect on their student teaching placements and to identify one academic behavior that they wanted to change. They brainstormed issues among themselves and developed research questions. Elliott (as cited in Holly, Arhar, \& Kasten, 2005) describes the action research process as beginning with a feeling, a sense of frustration, a sense of creative possibilities for action, and the pronounced commitment to "do it differently, to bring one's practice in line with one's values and aspirations" (p. 5). When students struggled with disconnects between available research and their issues, they were forced to revise their questions and approach to the topic. The incorporation of the AR model (to the original EOSL project) enhanced their research by including a literature review, implications, and personal statement sections.

\section{PERSONAL STATEMENTS}

Personal statements were analyzed to help determine the perceptions and feelings of the teacher candidates towards AR. The emerging themes from the personal statements included: parent participation, professional gains/growth, appreciation for research, student achievement/individual student needs, action research and classroom procedures, home schooling perceptions, teacher observation, reflection, and collaboration. The personal statements revealed a positive overall effect. 


\section{CONCLUSIONS}

Throughout the semester there was concern with the teacher candidates' abilities to conduct research because they had no formal prior research experience. Discussing the components of AR and uploading them to Web/CT for easy access provided unlimited support. An AR textbook was not used, and, basically, teacher candidates were expected to learn the AR process on their own - and they did. Discussions and Q \& A sessions were incorporated into the seminars to reinforce outside readings and address issues related to individual projects.

Initially, teacher candidates did not regard themselves as teacher researchers; nor, did they view the action research project as valuable or beneficial to them as new teachers. However, once they began to analyze their data, the light bulb concept kicked in. They arrived at seminar with questions, insights, enthusiasm, and demonstrated a commitment to their research project. They became empowered with the student data and reflected on individual student abilities and progress or lack of progress. They explored the need to investigate the knowledge and experiences that each student brought to class to help them better plan and prepare appropriate lessons that built on that knowledge base.

\section{LIMITATIONS}

Teacher candidates' demonstrated resistance to the AR project. The principals and cooperating teachers at their placement sites agreed that the AR project was time consuming and unnecessary. Because this was the first semester to implement the AR, not all of the students completed projects that focused on content area academics. Several focused on handwriting and behaviors that were not connected to academic learning. Time was an issue. Teacher candidates only had one semester to learn the AR process, design a study, implement best practices, and collect and analyze data. In addition to the AR project, they were required to interview their cooperating teachers, write introductory letters to the parents of the students in their classrooms, conduct four outside classroom observations and submit written reflections; and complete an electronic portfolio.

\section{IMPLICATIONS FOR FURTHER RESEARCH AND PRACTICE}

Based on the personal statements and positive outcomes of this study, the teacher candidates proved there is a place for AR in the student teaching program. As the directors of the program, we plan to streamline the student teaching seminars to primarily focus on action research and teaching issues. An action research textbook will be valuable to support the compilation of materials provided and offer students with an additional reference.

Future research foci would be to follow these teacher candidates into their first three years of teaching to determine if, indeed, they incorporate AR in their teaching practice. Further study to determine the impact of the AR process on teachers preparing dossiers for the state's 3 -tier licensure program is needed.

\section{INSTRUCTOR STATEMENTS}

Students were asked to write personal statements reflecting on the AR experience. As seminar instructors, we were surprised by the in-depth reflection of the teacher candidates' experiences through their personal statements and curricula decision-making as reported in the action research final projects. Overall, they demonstrated the ability to write a literature review, create diagnostic assessments, analyze student data, and reflect on their teaching practices. The AR projects were effective in determining evidence of student learning in the K-12 classroom.

\section{REFERENCES}

1. Auger, W. \& Wideman, R. (2000). Using action research to open the door to life-long professional learning. Education, 21(1), 120-127.

2. Chant, R., Heafner, T., \& Bennett, K. (2004). Connecting personal theorizing and action research in preservice teacher development. Teacher Education Quarterly, 31(3), 25-42. 
3. Henderson, M., Hunt, S., \& Wester, C. (1999). Action research: A survey of AACTE-member institutions. Education, 119(4), 663-667.

4. Holly, M. L., Arhar, J., \& Kasten, W. (2005). Action research for teachers: Traveling the yellow brick road. Upper Saddle River, NJ: Pearson.

5. Kosnik, C. \& Beck, C. (2000). Who should perish, you or your students? Dilemmas of research in teacher education. Teacher Education Quarterly, 27(2), 119-135.

6. Moore, R. (1999). Preservice teachers engaged in reflective classroom research. The teacher Educator, 34(4), 259-275.

7. Rosaen, C. \& Gere, A. R. (1996). Both sides of the desk: Collaborative self-study in teacher education. Action in Teacher Education, 18, 56-67.

\section{NOTES}

